\title{
高齢者膀胱癌患者に対する術中照射ならびにその臨床的意義
}

\author{
東京都立駒込病院泌尿器科 \\ 篠原 充 山本 理哉 杉本 雅幸 木下 健二 \\ 東京都立駒込病院放射線科 \\ 田中 良明松 田忠義

\section{CLINICAL SIGNIFICANCES OF INTRAOPERATIVE RADIATION THERAPY FOR AGED PATIENTS WITH BLADDER CANCER} \\ Mitsuru Shinohara, Toshiya Yamamoto, Masayuki Sugimoto, Kenji Kinoshita, \\ Yoshiaki Tanaka* and Tadayoshi Matsuda* \\ Department of Urology and Radiology*, Tokyo Metropolitan Komagome Hospital
}

Seven elderly patients, 79 88 years old, with bladder cancer were treated by transvesical tumorectomy with intraoperative radiation therapy (IORT). The cancers appeared to be of high grade and high stage by cystoscopy and other examinations, and consequently they were diagnosed to be over stage $T_{2}$. Therefore, all patients were thought to be candidates for total cystectomy. But their ages and complications precluded this treatment, so we decided to carry out the "palliative" IORT.

The operation of IORT required less than two hours and required less than $200 \mathrm{ml}$ of blood loss. There were no complications such as hematuria, irritable bladder, and rectal symptoms.

The postoperative stage diagnoses coincided with the preoperative ones in 5 cases, but two cases were overdiagnosed. Five patients died after more than one year and 11 months, but four patients died due to other diseases, without cancer. One patient died due to pulmonary cancer confirmed by autopsy. Recurrence was seen in one case.

These results confirmed that IORT was effective for local control of bladder cancer and partially prophylactic for recurrence. Furthermore, this treatment seemed to be even curative for some cases. We recommend this modality of treatment for some of aged patients and patients with complications who are unable to undergo cystectomy.

Key words: bladder cancer, intraoperative radiation therapy, aged patients

\begin{abstract}
要旨： 7 例の高齢者膀脂癌患者（79 88歳）に対して術中照射を行った。膀脂鏡所見は全例，無茎ある いは広基性の径 $2 \mathrm{~cm}$ 以上の腫瘍であり術前診断はすべて $\mathrm{T}_{2}$ 以上であった。一般的に考えて, 膀胼全摘術 の適応であったが年齢打よび合併症のため根治的治療は不可能と判断したため, 腫瘍切除と同所再発の 予防を主目的に術中照射を行った，全手術時間はおよそ 2 時間程度で，出血も少なく合併症も認められ なかった。この治療法は合併症のある高齢者にとっても侵襲は少ない手術と考えられた。病理学的術後 診断では， 5 例は術前診断に一致したが 2 例は $\mathrm{T}_{1}$ であった。術後， 5 例が死亡したが，そのうち 4 例は 術後 1 年11カ月以降であり全例膀胼癌以外の原因で死亡した。再発による再入院は 1 例のみであった. 以上の結果は, 膀胱癌の存在による症状軽减を目的とした局所のコントロールとしては充分な効果があ り，さらにある程度は根治的であると思われた。 また再発予防効果もあると考兄られた。 今後, 高龄者 の患者増加が予想されるに当たり, 従来の根治的手術が不可能な症例に対する治療選択の一つとなると 考光る.

キーワード：膀胱癌, 術中照射, 高齢者
\end{abstract}

緒言

固形癌の治療の原則は, 手術的に可能な限り悪性細
胞を取り除き，もし残存する細胞があれば，各種の補 助的手段を用いてこれを除く点にある。しかし，本邦 
においては老龄化が進むにつれ，膀胱癌患者の症例で も重篤な合併症を持つ症例や超高齢者の症例が増加し て，多くの問題点により原則通りの治療ができず, 治 療法の選択に頭を悩むすことが多くなってきた。特に, high grade, high stage 症例では膀羘全摘術が最適で あるが，高齢者にとっては術前に合併症がなくとも手 術自体の危険性や術後合併症の頻度も高く，また手術 死亡率も高い1). 従って, 合併症のある高齢者では根治 的治療を諦めざるを得ない事も多い。しかし，このよ らな症例に打いても手をこまねいて放置することな く，短い予後をより快適に過ごせるように quality of life の面から治療を行うことが重要と考光る. 即ち, 根治が不可能にしてる膀胼癌の進展により生じる, 出 血や排尿痛・頻尿などの膀胱刺激症状を軽減し, 可能 な限り尿路変更などの手術を遅らせ, 発病前と同じ生 活をより長く保てるようにすることが重要であると思 われる。

我々の病院では, 術野に照射筒を挿入し放射線を照 射する術中照射 (intraoperative radiation therapy： IORT)が可能なため, 各種の悪性腫瘍に対して適応し てきた ${ }^{2)}$. 膀腅腫瘍においても膀羘全摘が最適の治療 法にもかかわらず高龄や合併症のため全摘が不可能な 症例と，全摘を拒否した患者の一部に対して術中照射 を行ってきた，今回この方法により，いわゆる根治的 治療が出来なかったにもかかわらず予後や再入院の点 から考えて, 満足すべき結果が得られたので, 治療内 容ならびに臨床的意義について報告する。

\section{対象}

対象は，根治的手術療法の適応にもかかわらず，各 種の理由によりその治療法が施行出来なかった患者で ある。即ち，1975年新病院開設以来，内視鏡手術ある いは薬物療法で治療不可能と考えられる患者でかつ膀 脱全摘が施行できなかった患者を対象とした。これら の患者の中で孤立性の $5 \mathrm{~cm}$ 以下の腫場に対して術中
照射を行ってきた. 全例で 7 名, 男子 5 名女子 2 名で, 年齢は79歳 6 力月から87歳 6 力月であった。平均年齢 は83歳11カ月であった（表 1 ）。根治的手術を行わな かった理由は，6 例は高齢で合併症による全身状態不 良のため, 手術時間や出血量より膀胼全摘が困難と考 えられたためであった。残り 1 例は手術可能と考えら れたが，高齢を理由に家族および本人が手術を拒否し たためであった。術前の Stage 分類は膀胱鏡所見・双 手診・IVP・CT・肝, 骨シンチグラフィーにより行っ た。一部の患者においては術中照射以前に行った経尿 道的腫場切除術による生検の結果も参考とした。腫瘍 は膀胼鏡で全例 $2 \mathrm{~cm}$ 以上でありすべて広基性か無茎 性で悪性度の高いことが示唆された. 経尿道的切除術 にては完全切除が困難と考えられ, 全例術前 $\mathrm{T}_{2}$ 以上と 診断した. IORT の手技上より, 腫湯は後壁あるいは側 壁に存在するものを対象とした。術前臨床病期は， $\mathrm{T}_{2}$ $\mathrm{N}_{0} \mathrm{M}_{0}$ が 5 例, $\mathrm{T}_{2} \mathrm{~N}_{0} \mathrm{M}_{1}$ が 1 例, $\mathrm{T}_{3} \mathrm{~N}_{0} \mathrm{M}_{0} 1$ 例であった. $\mathrm{M}_{1}$ の症例は, IORT 前に行った化学療法により腫瘍の 縮小が認められたため行った。

\section{方 法}

術中照射は手術的に膀胱を開き照射筒を創部に挿入 し放射線を照射する方法である，照射筒を前方ないし は斜前方より插入するため膀胱の後半分が治療対象と なる，手術法は以下の通りである。

手術室にて硬膜外麻酔下に砕石位か仰臥位をとり， 臍下ょり恥骨上をでの下腹部正中切開をおき, 恥骨上 で膀胼を開く．出来る限り腫場を電気メスにて切除し 周辺部分を凝固止血する。減菌布をかけそのままの状 態で手術台を特製の搬送車に移し患者を放射線治療部 に移送する，照射室ではベータトロン（島津製）照射 装置の下に手術台を固定し照射筒を創部に㨂入する. 観察鏡を見ながら腫瘍根部を含んでその境界の外側よ り扰よそ $1.0 \mathrm{~cm}$ 以上の幅を持たせ照射筒を膀胱粘膜 に密着させる。 その時出血や尿は出来る限り吸引し，

表 1 術前臨床所見

\begin{tabular}{c|c|c|c|l|c}
\hline 症例 & 年齢 & 性別 & 術前臨床病期 & \multicolumn{1}{|c|}{ 合 併 症 } & $\mathrm{PS}^{*}$ \\
\hline 1. & $87 \mathrm{Y} 6 \mathrm{M}$ & 男 & $\mathrm{T}_{2} \mathrm{~N}_{0} \mathrm{M}_{0}$ & 不整脈・潰瘍・難聴 & 3 \\
2. & $83 \mathrm{Y} 9 \mathrm{M}$ & 女 & $\mathrm{T}_{2} \mathrm{~N}_{0} \mathrm{M}_{0}$ & 腎機能低下・高血圧 & 2 \\
3. & $82 \mathrm{Y} 6 \mathrm{M}$ & 男 & $\mathrm{T}_{2} \mathrm{~N}_{0} \mathrm{M}_{0}$ & 糖尿病・悪性負血・狭心症 & 2 \\
4. & $79 \mathrm{Y} 7 \mathrm{M}$ & 男 & $\mathrm{T}_{2} \mathrm{~N}_{0} \mathrm{M}_{1}$ & 不整脈・閉塞性換気障害 & 4 \\
5. & $88 \mathrm{Y} 1 \mathrm{M}$ & 男 & $\mathrm{T}_{3} \mathrm{~N}_{0} \mathrm{M}_{0}$ & 完全右脚ブロック・腎機能低下 & 2 \\
6. & $81 \mathrm{Y} 1 \mathrm{M}$ & 男 & $\mathrm{T}_{2} \mathrm{~N}_{0} \mathrm{M}_{0}$ & 糖尿病・高血圧 & 2 \\
7. & $85 \mathrm{Y} 3 \mathrm{M}$ & 女 & $\mathrm{T}_{2} \mathrm{~N}_{0} \mathrm{M}_{0}$ & 混合性換気障害・食欲不振 & 2 \\
\hline
\end{tabular}

* 小山・斎藤班の分類による performance status 
表 2 手術所見および術中照射条件

\begin{tabular}{|c|c|c|c|c|c|c|c|}
\hline \multirow{2}{*}{ 症例 } & \multirow{2}{*}{ 手術時間 } & \multicolumn{5}{|c|}{ IORT } & \multirow{2}{*}{ 出血量 } \\
\hline & & 照射時間 & 照射筒 & エネルギー & 線量 & 深度 & \\
\hline 1. & 108分 & 26 分 10 秒 & $4 \mathrm{~cm}$ 円形 & $4 \mathrm{MeV}$ & $30 \mathrm{~Gy}$ & $1 \mathrm{~cm}$ & $200 \mathrm{ml}$ \\
\hline 2. & 147 & 15分 & $4 \times 2$ 楕円 & 6 & 30 & 1 & 370 (含尿) \\
\hline 3. & 127 & 19分11秒 & $4 \times 3$ 楕円 & 4 & 35 & 1 & 120 \\
\hline 4. & 130 & 25分 & 3 円形 & 4 & 30 & 0.5 & 65 \\
\hline 5. & 125 & 20分 & 円形 & 6 & 25 & 1 & 250 \\
\hline 6. & 90 & 15分11秒 & 4 円形 & 6 & 25 & 1 & 50 \\
\hline 7. & 80 & 4 分 15 秒* & 円形 & 6 & 25 & 1 & 40 \\
\hline
\end{tabular}

*スキャタラーを用いずに照射したため短時間である

表 3 術後臨床所見および経過

\begin{tabular}{|c|c|c|c|c|c|c|c|c|}
\hline 症例 & 術 & 診 & 断 & 再発 & 再入院 & 結 & 最終年齢 & 術後経過年数 \\
\hline 1. & TCC & Gr.3 & $\mathrm{pT}_{2} \mathrm{NxM}_{0}$ & 無 & 有 & 他病死 & 93 歳 6 力月 & 6 年 0 カ月 \\
\hline 2. & $\mathrm{TCC}$ and $\mathrm{AC}$ & Gr.3 & $\mathrm{pT}_{2} \mathrm{NxM}_{0}$ & 無 & 無 & 他病死 & 87 歳 1 カ月 & 4 年 5 力月 \\
\hline 3. & TCC & Gr.2 & $\mathrm{pT}_{2} \mathrm{NxM}_{0}$ & 有 & 有* & 他病死（癌有） & 88 歳 8 力月 & 5 年 10 力月 \\
\hline 4. & TCC & Gr.3 & $\mathrm{pT}_{2} \mathrm{NxM}_{0}$ & 無 & 無 & 他病死（肺癌） & 79歳11 & 3 力月 \\
\hline 5. & $\mathrm{TCC}$ and $\mathrm{SC}$ & Gr.3 & $\mathrm{pT}_{3} \mathrm{NxM}_{0}$ & 無 & 無 & 他病死 & 90 歳 0 & 1 年11力月 \\
\hline 6. & TCC & Gr.2 & $\mathrm{pT}_{1} \mathrm{Nx}$ & 無 & 無 & 生 存 & 83歳 2 & 2 年 1 力月 \\
\hline 7. & TCC & Gr.3 & $\mathrm{pT}_{1} \mathrm{NxM}_{0}$ & 無 & 有 & 生 存 & 85 歳 10 力月 & 7 力月 \\
\hline
\end{tabular}

$\mathrm{TCC}$ : 移行上皮癌, $\mathrm{SC}:$ 扁平上皮癌, $\mathrm{AC}:$ 腺癌, ${ }^{*}$ 他病院入院

その後放射線を照射する，途中，照射時間が長い場合 には，照射筒の位置が移動しないことを確認するため 二度に分割し放射線を照射する，照射終了後，手術室 に移動し通常の膀胖切開術にしたがって膀胼を閉じド レーンおよびバルーンカテーテルを留置して手術を終 了する。

\section{結 果}

手術(表 2)：手術時間は移動および照射を含めおよ そ 2 時間であった。輸血の必要になるような出血は無 かった，照射筒は $4 \times 2 \mathrm{~cm}$ の棈円〜 $4 \mathrm{~cm}$ の円形を使用 した。エネルギーは $4 \mathrm{Mev} \sim 6 \mathrm{Mev} て ゙$ 照射線量は $25 \mathrm{~Gy}$ 〜35Gy であった。目標深度は $0.5 \sim 1 \mathrm{~cm}$ とした。照射 時間は 4 分 30 秒 26 分 10 秒であった。

術後の臨床所見 (表 3 )：治療前の内視鏡的手術およ び術中照射時の手術標本による病理学的病期は，5例 が術前診断に一致し，2 例は $\mathrm{T}_{1}$ であった。 1 例のみは 手術時に腫場近傍に粘膜の発赤部の存在が発見され同 時に行った生検にて上皮内癌の存在が証明された。別 の 1 例では娘腫瘍が存在し同時に切除した。 その他の 症例を含め random biopsy は施行しなかった。

手術後の経過観察期間は 7 カ月から 5 年11カ月であ る. 術前 $M_{1}$ と診断された 1 例（症例 4 ）は部検により
原発性の肺癌による死亡が確認された，従って最終診 断は $\mathrm{M}_{0}$ であった。

予後(表 3 )：3 例が癌無く他病死， 1 例が癌の再発 を認めたため他院に人院し, 他の病気により死亡, 1 例が他癌死， 2 例は経過期間が短いが現在まで再発無 く生存している，以上の経過中 3 例が再入院した（表 3 , 症例 $1 ， 3 ， 7$ ). しかし， 1 例のみが再発による ものと推察された。

\section{考察}

悪性腫瘍の治療は, 老人においても出来る限り根治 的であることが望ましい，一般的に膀胖腫瘍は，low stage のものは経尿道的に膀胼を温存し治療され， high stage のものは尿路変更を伴う膀胼全摘術により 治療される ${ }^{1)}$. 手術的治療が困難な症例に対しては姑 息的な治療が試みられている。しかし，膀胱腫瘍は経 尿道的手術で処置される low stage の症例, 特に high grade では再発が多く ${ }^{1)}$, 頻回の再入院が必要となる. 更に high stage 症例では, 膀脱全摘術が必要であるが 侵襲の大きい手術であるため, 予後や手術の合併症さ らに尿路变更の管理などを考えると躊躇することも多 い. 一方, 根治的手術が施行出来ない時, 化学療法や 免疫学的療法・放射線療法などが試みられている。し 
かし，その効果と副作用を考皇ると，高㱓者に対して はやむを得ず対症療法だけとなり，血尿のコントロー ル・膀胱刺激症状の改善さらに閉塞性腎不全の改善な どを目的に尿路变更のみを行わざるを得ないことも多 く理想的治療法とは言いがたい。

術中照射は，本邦において阿部らが臨床的に開始し 発展させてきた方法である ${ }^{3)}$ ５)。この治療法の目的は 大きく分けて 3 種に分類することができる6). 第一に, 深部臓器の悪性腫瘍で手術のみでは完全な切除が不可 能で治療が明らかに不十分な時少しでも治療効果を上 げる目的で姑息的に行われる，第二に，手術で一応の 治癒的切除が行われたと考兄られるが予後から見て不 十分であり，肉眼では確認できない腫崵播種を予防し 治療成績を上げる目的で，いわゆる予防的照射として の適応である，第三に，手術的には根治が期待できる が機能の温存をはかり, 手術的切除部位をより减少さ せる目的があげられる。

膀胱腫瘍に対しても多くの施設で IORT が試みら れている7) 11). 手術方法は, 一般に今回の報告と同じ であるが腫瘍切除を行ら報告と行わない報告がある。 さらに切除部位を照射筒に合わせて縫縮しより大きな 腫場にも試みる方法もある。この治療法の理論的バッ クグランドは, 膀胱部分切除と同じく膀胖機能を温存 し，しかも根治を期待することである ${ }^{12) ~ 15) . ~ し か し ， ~}$ 膀胱全摘術においてさえリンパ管や血管など脈管侵襲 の明らかな症例では再発・癌死が多く, いわんや IORT においては, 病期診断が不正確なため現在のところ一 般的に勧められる治療法とは言いがたい。これまでの 報告に怙ける本法の適応は, Stage は不正確だが根治 を目的としたものが多(9111). Matsumoto らは各種の Stage の膀胼癌に対して腫瘍切除を伴わないIORT を行った結果を報告している ${ }^{11)} . \mathrm{T}_{1} ・ \mathrm{~T}_{2}$ では 1 年, 2 年および 5 年以内の異所性の再発はそれぞれ $5.2 \%$, $9.4 \%, 19.3 \%$ と再発予防効果を認め, 更に 5 年生存率 も $96.3 \% ， 61.6 \%$ と良好な結果であった。しかし，こ れらの Stage 症例の多くは内視鏡的手術で治療可能 と考えられ, 再発予防として最近では BCG の注入療 法で良い結果が示されているため16)17)現在この目的で 使用されることは少ないと考号れる。

一方, 彼らの報告によれば $\mathrm{T}_{3} \mathrm{~T}_{4}$ の 5 年生存率は $7.3 \%$ で根治的には不十分であった。浸潤癌に対して腫 瘍切除と IORT の組み合わせ, あるいは腫瘍切除と IORT およびその他の治療法を組み合わせて根治的目 的で試みられた報告もある99.これらの報告の中には
5 年生存率は $\mathrm{T}_{3} \mathrm{~T}_{4}$ 群においても $\mathrm{T}_{1} \mathrm{~T}_{2}$ 群と差を認め ないとするものもあるが8)，いずれにしろ浸潤癌に対 する例は少数のため明らかな意義を示すことはできて いない18)．藤田らは局所浸潤の疑われる症例に IORT を行い, 直径 $2 \mathrm{~cm}$ 以下の単発性腫瘍で $\mathrm{T}_{2}$ 以下のもの で特に同所再発を繰り返すものが適応になるとしてい る7). IORT 療法は理論的には部分切除と同じであり 藤田らも述べているよらに, 症例を選べば根治的療法 と変わらぬ効果が期待できると思われる。しかし, 術 中照射時の切除あるいは生検標本は当然のことながら 全層標本でないため症例の stage 分類を正確に行らこ とは困難である。また，リンパ管や血管浸潤を診断す ることは不可能に近いためその適応には慎重に成らざ るを得ない。

今回我々は, 従来の膀胱癌に対する IORT の適応と は異なり，根治的治療が不可能と考えられる高齢者膀 胼癌患者に対してのみ姑息的方法として術中照射を試 みた，再発は 7 例中 1 例のみに認めた。従来の low stage 症例に対する内視鏡手術における再発率の報告 では，経過年数が異なるものの 1 年〜 5 年で $55 \sim 75 \%$ と非常に高い. ${ }^{19)}$. また, 部分切除術でも 3 年で $50 \%$ 以上 の再発を示したり ${ }^{15)}$ ，対象を非常に限定した場合でも 全体で38\%とする報告があり ${ }^{14)}$, 再発率は高い。これら の結果と比較しても今回の成績 (14.3\%) は十分良好 と考えられる。病理学的浸潤度が低い $T_{1}$ を含んでいる ことや, 経過観察期間が限られているにせよ再発予防 効果があると考えられる。

今回の対象患者 7 例中 5 例が IORT 療法後死亡し た。しかし，1例は他の癌による死亡で，再発した 1 例も他病死であった. Kaplan-Meier 法による 3 年お

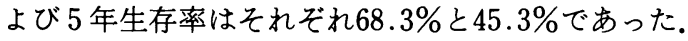
主に high stage 症例が適応となる膀胱部分切除およ び全摘術の $\mathrm{T}_{2}$ 症例に括ける 5 年生存率がそれぞれ 27 80\%拈よび13〜87\%程度であること，さらに 83 歳 の平均余命が男女でそれぞれ5.46年と6.37年から考兄 て ${ }^{20)}$ ，かなり良い成績と思われる。再発例を除いた死亡 例全員が死亡時までに膀胱癌の存在による症状を示さ ず，治療処置も必要としなかった。また遠隔転移を示 寸所見・症状も無かった。 以上の結果から考光ると， 再発例以外の残り 4 例では根治とは断定できないもの の 1 年11カ月以上血尿・疼痛などの症状を示すことな く予後を過ごし発病前の生活状態と同じ状態を続ける 事ができ治療効果として十分であり臨床的には根治と 考えてよいと思われる，特に症例 4 は，剖検により肺 
癌による死亡と膀胱癌の完全消失が証明されている. さらに生存の 2 例では経過観察期間が短いが，現在ま で再発なく目的の効果があったと考学られる。

\section{結 語}

今回述べた方法は, IORT を組み合わせても手術自 体は 2 時間程度ですみ出血も少量であり簡便な手術法 であると言学る，従って，合併症のある高齢者に対し ても十分に行える治療法の一つであると言える、今回 の術中照射は, 膀胱腫場の存在に上る血尿・膀胱刺激 症状を予防し，また再発による頻回の入院を予防寸る 目的として期間は短いかもしれないが平均年齢83歳 11 カ月の高齢者としては十分な効果があったと考学られ る. 更に, この結果から見る限り, IORT は一定の症例 に対しては根治的治療になり得る可能性もある。危険 を侵してまで根治的膀脱全摘術の施行を躊躇する場合 には, 開創照射の設備のある施設に限られるものの, 選択の一つに入れる治療法であると考える。

\section{文献}

1) Droller, M.J.: Transitional cell cancer : Upper tracts and bladder. in Campbell's Urology, Walsh, P.C., Gites, R.F., Perlmutter, A.D. and Stamey, T.A., Fifth ed. p. 1343, Saunders Co., Philadelphia, 1986.

2）田中良明, 竹下祥敬, 松田忠義, 岡本篤武, 松谷雅 生, 田畑育男, 江川直人：治療可能比からみた術中 照射療法の臨床的意義. 癌の臨林, 33, 1619-1626, 1987.

3）阿部良悦, 加藤哲郎, 森 久, 佐藤一成, 森山正 風, 村上優子, 加藤敏郎：泌尿器癌に対する術中照 射の試み. 日癌治療会誌, 22, 1145-1152，1987.

4) Abe, M., Takahashi, E. and Yabumoto, E.: Intraoperative radiotherapy of advanced cancers. Strahlentherapie., 146, 396-402, 1973.

5) Abe, M., Takahashi, M., Yabumoto, E., Adachi, H., Yoshii, M. and Mori, K. : Clinical experiences with intraoperative radiotherapy of locally advanced cancers. Cancer, 45, 40-48, 1980.

6) Goldman, A. : Past, present, and prospects of intraoperative radiotherapy (IOR). Semin. Oncol., 8, 59-64, 1981.

7）藤田公生, 村山猛男, 成田佳乃, 御屍修一：膀胱癌 に対する膀胼を保存した術中照射の適応と限界。 医療，41，592-595，1987.

8）村上義敬, 桜井智康, 西尾正道, 藤江順一郎, 大室 博: 膀胱癌の術中照射. 日本医放会誌, 45 ,
1017-1022, 1985.

9）田利清信, 佐竹一郎, 竹内信一, 砂倉瑞良：膀脱全 摘除術不能の進行膀胀腫湟に対する術中照射. 臨 泌，39，415-419， 1985.

10) Martinez, A. and Gunderson, L.L.: Intraoperative radiation therapy for bladder cancer. Urol. Clin. North. Am., 11, 693-698, 1984.

11) Matsumoto, K., Kakizoe, T., Mikuriya, S., Tanaka, T., Kondo, I. and Umegaki, Y.: Clinical evaluation of intraoperative radiotherapy for carcinoma of urinary bladder. Cancer, 47, 509-513, 1981.

12) Prout, G.R. Jr.: The role of surgery in the potentially curative treatment of bladder carcinoma. Cancer Reseach, 37, 2764-2770, 1970.

13) Long, R.T.L., Grummon, R.A., Spratt, J.S. Jr., Perez-Mesa, C.: Carcinoma of the urinary bladder (Comparison with radical, simple, and partial cystectomy and intravesical formalin). Cancer, 29, 98-105, 1972.

14) Kaneti, J.: Partial cystectomy in management of bladder carcinoma. Eur. Urol., 12, 249-252, 1986.

15）本間之夫, 親松常男, 岩動孝一郎, 堀内誠三：膀腅 部分切除術の治療成績一移行上皮腫崵55例の検討 一。 日泌尿会誌，79，1723-1727，1988.

16) Morales, A.: Long-term results and complications of intracavitary Bacillus Calmette-Guerin therapy for bladder cancer. J. Urol., 132, 457-459, 1984.

17）萩原正道, 大東貴志, 中薗昌明, 朝倉博孝, 塚本拓 司, 飯ヶ谷知彦, 山本 正, 实戸清一郎, 林暁, 山本秀伸：表在性膀胼腫瘍に対する BCG 膀腅内 注入療法の検討一乳頭状腫崵に対する腫場縮小招 よび再発予防効果一. 日泌尿会誌, 79, 521-526, 1988.

18）田利清信, 佐竹一郎, 児島真一, 辻井俊彦, 砂倉瑞 良：膀朕腫境に対する膀腅保存療法としての腫煌 切除併用術中照射術. 癌の臨床, 33, 1805-1809, 1987.

19) Gibson, R.P.: Results and follow-up of bladder tumors following transurethral resection. in Bladder Cancer, Part A : Pathology, Diagnosis, and Surgery, Küss, R., Khoury, S., Denis, L.J., Murphy, G.P. and Karr, J.P., p. 359, Alan, R. Liss, Inc., New York, 1984.

20）厚生の指標. 臨時増刊, 国民衛生の動向，36巻, 厚 生統計協会, 1989.

（1990年 5 月 2 日受理） 